to 4.75 inches by 9 inches and can readily slip into a pocket or glove compartment.

Although aimed at children this is a useful tool for the non-geologist adult who does not have the time (or inclination) to master the complex technology of geological science. I have a habit of picking up small

\section{New Titles}

Prepared by Roy John

$\dagger$ Available for review * Assigned

\section{ZoOLOGY}

The Amphibians of Belarus. By S. Drobenkov, R. Novitsky, L. Kosova, K. Ryzhevich, M. Pikulik. 2006. Pensoft Publishers, Geo Milev Street 13a, 1111 Sofia, Bulgaria. 176 pages. EURO 34.00 Paper.

The Amphibians and Reptiles in Bulgaria. By V. Beshkov and K. Nanev. 2006. Pensoft Publishers, Geo Milev Street 13a, 1111 Sofia, Bulgaria. 120 pages. EURO 38.90 Cloth.

* Animal Skulls, A Guide to North American Species. By Mark Elbroch. 2006. Stackpole Books, 5067 Ritter Road, Mechanicsburg, Pennsylvania 17055 USA. 448 pages. $\$ 44.95$ PB 740 pages.

Atlas of Bird Migration. By J. Elphick (Editor) 2006. Firefly Books, 66 Leek Crescent, Richmond Hill, Ontario L4B 1H1 Canada. 176 pages. \$35 Cloth.

Birder's Companion. By S. Moss. 2006. Firefly Books, 66 Leek Crescent, Richmond Hill, Ontario L4B 1H1 Canada. 192 pages, \$16.95 Paper.

* Bird Conservation Implementation and Integration in the Americas: Proceedings of the Third International Partners in Flight Conference [on CD]. By C. J. Ralph and T. Rich. 2007. USDA, Redwood Sciences Laboratory, 1700 Bayview Drive, Arcata, California 955231 USA.

Birds of the Dominican Republic and Haiti. By S. Latta, C. Rimmer, A. Keith, J. Wiley, H. Raffaele, K. McFarland and E. Fernandez. 2006. Princeton University Press, 41 William Street, Princeton, New Jersey 08540-5237 USA. 360 pages. U.S. $\$ 35$.

Birds: A Visual Guide. By J. Burger. 2006. Firefly Books, 66 Leek Crescent, Richmond Hill, Ontario L4B 1H1 Canada. 304 pages. \$29.95 Cloth.

Birds of the World. Edited by A. Gossler. 2006. Firefly Books, 66 Leek crescent, Richmond Hill, Ontario L4B 1H1 Canada. 384 pages. \$39.95 Cloth.

A Birdwatcher's Companion to North American Birdlife. By C. Leahy. 2006. Princeton University Press, 41 William Street, Princeton, New Jersey 08540-5237 USA. 1072 pages. U.S. $\$ 19.95$

Southern African Birdfinder. Callan Cohen, Claire Spottiswoode and Jonathan Rossouw. 2006. New Holland Publishers (UK) Ltd., Garfield House, 86-88 Edgware Road, London W2 2EA, U.K. 456 pages, $£ 19.99$ Paper

100 Butterflies and Moths - Portraits from the tropical forests of Costa Rica. By J. Miller, D. Janzen and W. rocks and pebbles from the places I visit. I have not been consistent in identifying them, but I am sure this pamphlet will help me improve.

ROY JOHN

2193 Emard Crescent, Beacon Hill North, Ottawa, Ontario K1J 6K5 Canada

Hallwachs. Harvard University Press, 79 Garden St., Cambridge, Massachusetts 02138, USA. 260 pages. U.S. \$39.95.

*A Field Guide to North Atlantic Wildlife. By N. Proctor and P. Lynch. 2006. Yale University Press, P.O. Box 209040, New Haven, Connecticut 06520-9040 USA. 221 pages. U.S. $\$ 19.95$.

$\uparrow$ Conservation of the Black-tailed Prairie Dog. Edited by J. Hoogland. 2006. Island Press, 1718 Connecticut Avenue, NW, Suite 300, Washington D.C. 20009. 368 pages. U.S. \$35 Paper.

$\dagger$ The Northern Goshawk: A technical Assessment of its Status, Ecology and management. Edited by M. Morrison. 2006. Cooper Ornithological Society, c/o Western Foundation of Vertebrate Zoology, 439 Calle San Pablo, Camarillo California 93012-8506, USA. 369 pages. U.S. \$23 Paper.

* Migrating Raptors of the World - Their Ecology and Conservation. By Keith L. Bildstein. 2006. Cornell University Press, 512 East State Street, Ithaca, New York 14850 USA. 344 pages. $\$ 35.00$ Cloth.

Rattlesnake Adventures: Hunting with Oldtimers. By J. Kemnitzer, Jr. [Editor]. 2006. Krieger Publishing Company, P.O. Box 9542, Melbourne, Florida 32902-9542. 236 pages. U.S. $\$ 32.50$.

Atlas of the Millipedes (Diplopoda) of Britain and Ireland. By P. Lee. 2006. Pensoft Publishers, Geo Milev Street 13a, 1111 Sofia, Bulgaria. 216 pages. EURO 32.00 Cloth.

An Atlas of the Reptiles of North Eurasia. Taxonomic Diversity, Distribution, Conservation Status. By N. Ananjeva, N. Orlov, N. Khalikov, R. Darevsky, I. Ryabov, I. Barabanov. 2006. Pensoft Publishers, Sofia-Moscow. 250 pages. EURO 75.00 Cloth.

* Songbird Journeys: Four Seasons in the Lives of Migratory Birds. By Mary Chu. 2006. Walker \& Company, 104 Fifth Avenue, New York, New York 10011 USA. 312 pages. U.S. \$23.00 Cloth.

Snake Venoms and Evenomations. By J-P. Chippaux. 2006 English Edition. Krieger Publishing, P.O. Box 9542, Melbourne, Florida 32902 USA. 300 pages. U.S. \$58.50.

$\dagger$ Tracks. By D. Jackson. 2006. University Press of Mississippi, 3825 Ridgewood Road, Jackson, Mississippi 39211 USA. \$36.25 279pages. Cloth.

The Alligator Snapping Turtle. By P. Pritchard. 2006 reprint. Krieger Publishing, P.O. Box 9542, Melbourne, Florida 32902 USA. 152 pages. U.S. \$42. 
* Turtles of the World. By F Bonin, B Devaux and A Dupre. 2006. The Johns Hopkins University Press, 2715 North Charles Street, Baltimore, Maryland 21218-4363, USA. 416 pages. U.S. \$50 Cloth.

Whales, Dolphins and Seals - A Field Guide to the Marine Mammals of the World. By Hadoram Shirihai and Brett Jarrett. 2006. NHBS Environment Bookstore, 2-3 Wills Road, Totnes, Devon TQ9 5XN, U.K. 384 pages, £12.99 Cloth.

\section{BOTANY}

Botanical Riches - Stories of Botanical Exploration. By R. Aitken. 2007. Ashgate Publishing, Box 2225, Williston Vermont 05495. 256 pages. U.S. \$ 50 Cloth.

Wildflowers of the Rocky Mountains. By G. Scotter. 2006. Firefly Books, 66 Leek Crescent, Richmond Hill, Ontario L4B 1H1 Canada. 256 pages. \$29.95 Paper.

* Wild Orchids of the Canadian Maritimes and Northern Great Lakes Region. By Paul Martin Brown. 2006. University Press of Florida, 15 Northwest $15^{\text {th }}$ Street, Gainesville, Florida 32611-2079 USA. 366 pages. U.S. \$ 29.95

* Wild Orchids of the Pacific Northwest and Canadian Rockies. By Paul Martin Brown. 2006. University Press of Florida, 15 Northwest $15^{\text {th }}$ Street, Gainesville, Florida 326112079 USA. 304 pages. U.S. \$ 29.95

\section{ENVIRONMENT}

Algonquin Souvenir. By M. Runtz. 2006. Firefly Books, 66 Leek Crescent, Richmond Hill, Ontario L4B 1H1 Canada. 96 pages. \$19.95 Cloth.

An Artist's and Photographer's Guide to Wild Ontario. By R. Stimson and C. Thompson. 2006. Firefly Books, 66 Leek Crescent, Richmond Hill, Ontario L4B 1H1 Canada. 224 pages. \$29.95 Paper.

The Enchantment of Birds. By R. Cannings. 2007. Greystone Books, Suite 201, Quebec Street, Vancouver, British Columbia V5T 4S7 Canada. 168 pages. \$29.95 Cloth.

The International Politics of Bird Conservation. By R. Boardman. 2006. Edward Elgar Publishing, 9 Dewey Court, Northampton, Massachusetts 01060 USA. 288 pages. U.S. $\$ 110$ Cloth.

* The Atlas of Climate Change. By Kirstin Dow and Thomas E. Downing. 2006. NHBS Environment Bookstore, 2-3 Wills Road, Totnes, Devon TQ9 5XN, U.K. £12.99, Paper.

Principles of Population Genetics $-4^{\text {th }}$ edition. By D. Hart and A. Clark. Sinauer Associates, Box 407, Sunderland, Massachusetts 01375 USA. 565 pages. U.S. \$93.95.

An Inconvenient Truth. By Al Gore. 2006. NHBS Environment Bookstore, 2-3 Wills Road, Totnes, Devon TQ9 5XN, U.K. $£ 14.99$.

The Rough Guide to Climate Change. By Robert Henson. 2006. NHBS Environment Bookstore, 2-3 Wills Road, Totnes, Devon TQ9 5XN. U.K. £9.99.
* The Reluctant Mr. Darwin: An Intimate Portrait of Charles Darwin and the Making of His Theory of Evolution. By David Quammen. 2006. Atlas Books, 10 East 53rd Street, 36th Floor, New York, New York 10022, USA. 304 pages. U.S. \$22.95.

$†$ Marshes. By W. Burt. 2007. Yale University Press. P.O. Box 209040, New Haven, Connecticut 06520-9040 USA. 192 pages. U.S. \$35 Paper.

Nature's Engraver - A life of Thomas Bewick. 2007. Farrar Straus Giroux, North Point Press, 19 Union Square West, New York, New York 10003. 480 pages. \$27.50 Cloth.

Wild Nova Scotia. By L.Wagg. 2006. Nimbus Publishing, Box 9166, Halifax, Nova Scotia B3K 5M8 Canada. 96 pages. $\$ 29.95$.

People, Fish and Whales - The Vancouver Aquarium Story. By Dr. Murray Newman. 2006. Harbour Publishing, P.O. Box 219, Madeira Park, British Columbia VON 2H0 Canada. 120 pages. \$19.95 Paper.

* Pilgrimage to Vallombrosa - From Vermont to Italy in the Footsteps of George Perkins Marsh. By John Elder. 2006. University of Virginia Press, 210 Sprigg Lane, Charlottesville, Virginia 22903 USA. U.S. \$33.99 Cloth.

Sarcophaginae et Paramacronychiinae du Proche Orient (Insecta, Diptera, Sarcophagidae). By A. Lehrer. 2006. Pensoft Publishers, Sofia-Moscow. [In French.], 264 pages. EURO 64.00 Cloth.

Tales from the Thébaïde- Reflections of a Turtleman. By P. Pritchard. 2006. Krieger Publishing Company, P.O. Box 9542, Melbourne, Florida 32902-9542 USA. 340 pages. U.S. $\$ 44.50$.

Wild Borneo. By N. Garbutt and J. Prudente. 2006. The MIT Press, Five Cambridge Center, $4^{\text {th }}$ Floor, Cambridge, Massachusetts 02142-1493 USA. 176 pages. \$34.95 U.S.

The End of the Wild. By S. Meyer. 2006. The MIT Press, Five Cambridge Center, $4^{\text {th }}$ Floor, Cambridge, Massachusetts 02142-1493 USA. 96 pages. U.S. \$14.95.

$\dagger$ Wildfire in the Wilderness. By C. Czajkowski. 2006. Harbour Publishing, P.O. Box 219, Madeira Park, British Columbia V0N 2H0 Canada. 224 pages. \$19.95.

Endangered Wildlife on the Brink of Extinction. By G. McGavin. 2006. Firefly Books Ltd., 66 Lark Crescent, Richmond Hill, Ontario L4B 1H1 Canada. 142 pages. \$35. Cloth.

\section{YOUNG NATURALISTS}

Tale of a Great White Fish - A sturgeon story. 2007. Greystone Books, Suite 201 Quebec Street, Vancouver, British Columbia V5T 4S7 Canada. 48 pages. \$10.95 Cloth.

\section{Special Note}

Sale of the Herpetological Library of Adrian Crane (800 items including antiques). PDF catalogue from Breck@herplit.com 